\title{
REVIEW INDIKATOR DARI INDEK PSA NOAA UNTUK IKAN PELAGIS KECIL (TEMBANG: Sardinella sp.; Famili Clupeidae) DAN IKAN DEMERSAL (KURISI: Nemipterus sp.; Famili Nemipteridae)
}

\author{
Indicator Review of NOAA PSA Index for Small Pelagic Fishes (Tembang: Sardinella sp.; \\ Famili Clupeidae) DAN Demersal Fishes (Kurisi: Nemipterus sp.; Famili Nemipteridae)
}

Oleh:

Yonvitner ${ }^{*}$, Isdradjad Setyobudiandi ${ }^{1}$, Ahmad Fachrudin ${ }^{1}$, Ridwan Affandi1, Etty Riani ${ }^{1}$, Nur Triramdhani ${ }^{2}$

\footnotetext{
1 Departemen Manajemen Sumberdaya Perairan, Fakultas Perikanan dan Ilmu Kelautan, Institut Pertanian Bogor 2 Alumni Manajemen Sumberdaya Perairan, Fakultas Perikanan dan Ilmu Kelautan, Institut Pertanian Bogor

*Korespondensi: yonvitr@yahoo.com
}

Diterima: 07 Februari 2016; Disetujui: 20 September 2017

\begin{abstract}
Fishing activity have been caused change of fish's structure community and stock depletion. In the future, this phenomenon also give impact to disturbance the stock sustainability. The study of vulnerability to be relevant before decide that stock has been depleted. The vulnerability study that has been developing based on productivity indicator, particularly for big pelagic fish. This research was conducted from any sources data that relevant to review indicator performance based on statistic approach with mean and confidence interval. PSA parameter for Sardinella and Nemipterus differ from others. This data relevant to apply as reference point for tropical small pelagic fish.
\end{abstract}

Keywords: demersal, indicator, pelagic, performance, PSA

\section{ABSTRAK}

Aktifivitas penangkapan terus mendorong terjadinya perubahan struktur komunitas ikan yang dapat menyebabkan penurunan stok dan keberlanjutan. Kajian kerentanan menjadi relevant sebelum memutuskan bahwa stok tersebut diambang penurunan. Kajian kerentanan yang dikembangkan selama ini adalah kelompok ikan pelagis besar. Kajian ini dilakukan untuk merevisi indikator produktivitas sehingga bisa adaptif bagi ikan pelagis kecil. Data dikumpulkan dari berbagai sumber data sekunder untuk kemudian diolah secara statistik dengan pendekatan nilai rataan (mean) dan confidence interval untuk menentukan batas atas dan batas bawah. Hasil kajian menunjukkan bahwa parameter PSA untuk ikan tembang secara umum berubah dari kriteria PSA sebelumnya, begitu juga dengan ikan kurisi. Hasil modifikasi ini diharapkan dapat digunakan sebagai reference point bagi ikan pelagis kecil dalam analisis PSA yang lebih tepat bagi ikan ikan tropis.

Kata kunci: demersal, indikator, pelagis, performa, PSA 


\section{PENDAHULUAN}

Tingkat pemanfaatan sumberdaya ikan sangat masif dan cenderung eksploitatif berisiko menyebabkan kerentanan. Kondisi ini dapat mengancam kelangsungan hidup populasi ikan tersebut. Risiko keterancaman dapat berupa kematian atau kepunahan, sehingga keberlanjutan tidak terjadi. Aktivitas perikanan seperti ini berada dalam kondisi terancam (risk condition), termasuk habitat (Cheung et al. 2005). Dengan kata lain kerentanan dapat didefenisikan sebagai suatu kondisi dimana sumberdaya ikan mengalami tekanan karena proses penangkapan. Perkembangan studi kerentanan ikan banyak dikembangkan, dan sering dikaitkan dengan kondisi perubahan iklim. Millner (2007) meneliti tentang kerentanan ikan tuna sebagai kelompok pelagis besar dari tuna tropis. Sumaila et al. (2012) menggunakan pendekatan kerentanan pada bluefin tuna di Mediteranean. Adapun Luna et al. (2014) mengkombinasikan kajian kerentanan di Teluk Meksiko.

Kerentanan ini dapat terjadi karena perubahan struktur biologi, terganggunya fungsi ekologisnya dan lingkungan (Navas 2011). Perubahan struktur biologi secara nyata mempengaruhi kemampuan pulih populasi mencapai struktur yang layak untuk eksploitasi, sedangkan gangguan terhadap struktur ekologi selain kemampuan pulih juga indikator sosial masyarakat (Luna et al. 2014) yang menggantungkan hidupnya pada aktivitas usaha perikanan.

Berbagai metode analisis risiko beberapa tahun terakhir ini banyak dikembangkan untuk melihat kerentanan sumberdaya ikan juga bersifat multi variabel. Metode ini selalu memadukan berbagai jenis dan bentuk data yang tersedia. Pendekatan analisis multi variabel sesuai dengan kepentingan perikanan Indonesia, karena mencakup berbagi dimensi yang dipertimbangkan dalam mengkaji perikanan.

Adopsi metode kerentanan harus memperhatikan kondisi perikanan dan kepentingan Indonesia. Salah satu metode analisis risiko yang dikembangkan NOAA juga sudah dikembangkan di Indonesia. Pendekatan kerentanan menurut NOAA lebih dominan menggunakan batasan untuk ikan pelagis besar seperti tuna dengan kisaran nilai parameter produktivitas yang lebih tinggi jika dibandingkan dengan ikan pelagis kecil.

Pendekatan kerentanan NOAA disusun berbasis data biologi (life history) dengan mempertimbangkan struktur populasi dengan mengkombinasikan berbagai parameter (integrative approach) (Peterson 2010). Kemudian disusun batasan batasan dalam skala biologi dan ekologi ikan pelagis besar. Selanjutnya dilakukan analisis komposit terhadap parameter tersebut. Secara prinsip metode ini dapat diadopsi oleh perikanan Indonesia baik pelagis besar, namun perlu adaptasi dan modifikasi untuk ikan pelagis kecil, karena nilai parameter life history yang berbeda.

Modifikasi nilai parameter adalah langkah yang sangat baik dan perlu dilakukan adalah agar lebih adaptif. Modifikasi ini terutama untuk kelompok ikan pelagis kecil, demersal dan ikan karang. Kajian dalam tulisan ini ditekan pada upaya evaluasi nilai dari batasan indicator life history ikan tembang dan ikan kurisi mewakili ikan pelagis kecil dan demersal kecil.

Ikan tembang termasuk kelompok pelagis kecil yang sebagian besar hidup di permukaan perairan, dan ikan kurisi termasuk kelompok ikan demersal karang. Kedua ikan ini termasuk ikan yang memiliki siklus hidup (life history) yang lebih pendek dari ikan pelagis besar. Modifikasi mencakup batasan nilai skor dari parameter yang dipakai bagi ikan pelagis kecil dan demersal karang. Batasan ini merupakan hasil telaahan dari setiap parameter life history yang menjadi indikator kunci dalam kajian ini. Studi ini membatasi pada dua jenis yaitu Sardinella sp. sebagai species pelagic neritic (Gerasmio et al. 2015) dan Nemipterus sp. sebagai representasi demersal neritic. Penelitian ini bertujuan mengevaluasi nilai indikator dan batasan parameter kerentanan menurut NOAA yaitu parameter productivitas agar lebih adaptif dengan spesies contoh ikan pelagis kecil dan ikan demersal kecil.

\section{METODE}

Pengumpulan data primer dilaksanakan selama Februari-Juni 2014. Evaluasi dilakukan dari data yang dikumpulkan dari Pelabuhan Perikanan Pantai Labuan, Pelabuhan Perikanan Nusantara Karangantu Banten serta beberapa data kajian yang sudah dilakukan. Pengumpulan data dan analisis dilakukan di Laboratorium Basah Manajemen Sumberdaya Perikanan, MSP-FPIK IPB

Lingkup penelitian ini terdiri dari data biologi, dinamika populasi dan morfology ikan tembang dan kurisi. Secara umum beberapa data dasar yang penting dan juga dikumpulkan diantaranya pengukuran data panjang, berat, kuisioner tentang hasil penangkapan serta praktek-praktek penangkapan.

- Pertama ikan hasil tangkap diidentifikasi dengan cepat (rapid assessment), kemudian dilakukan pengambilan contoh secara acak untuk masing-masing spesies ikan berdasarkan ukuran ikan. Jumlah ikan contoh 
harus mewakili ukuran ikan yang ada di lokasi tersebut.

- Kemudian masing-masing jenis ikan diukur panjang dan beratnya, Data panjang ikan diukur dimulai dari mulut terdepan ikan hingga pangkal tulang ekor. Data berat ikan diambil dari bobot basah berat tubuh ikan.

- Dari contoh ikan yang telah diukur, maka diambil sekitar 10-20 ekor ikan untuk dibedah dan diambil gonadnya, kemudian gonad tersebut diawetkan dengan menggunakan formalin 4\% untuk analisis reproduksi.

Data kuisioner dikumpulkan melalui wawancara dengan nelayan dan pihakterkait. Pihak tersebut diantaranya pengurus koperasi dan dinas perikanan kelautan setempat. Data yang dikumpulkan meliputi data jenis alat tangkap, jenis kapal, operasi penangkapan, daerah fishing ground, harga jual, pendapatan nelayan, jenis ikan lain yang ikut tertangkap. Data yang terkumpul dikelompokkan menurut jenis data untuk kemudian dikaji secara statistik nilai tengah, simpangan dan selang kepercayaanya.

\section{Parameter Produktivitas}

Jumlah dan jenis parameter kajian mengacu pada parameter yang sudah dikembangkan oleh NOAA. Parameter yang dikaji dalam penelitian ini adalah produktivitas karena lebih sensitive (Fenner 2014). Parameter produktivitas menurut Patrick et al. (2009) dijadikan basis, karena perubahan stabilitasnya dapat terpantau dari dinamika perubahan data setiap jenis ikannya (Miller 2007) seperti disajikan pada Tabel 1.

\section{Skor Atribut NOAA}

Kriteria kerentanan yang dikembangkan NOAA Patrick (2009) untuk atribut produktivitas terdiri dari 10 parameter dengan nilai dan rangking skala 3 . Rangking terendah bernilai 1 yang menyatakan bahwa nilai parameter tersebut mengindikasi risiko yang rendah, 2 risiko sedang dan 3 risiko tinggi. Jika rangking besar, maka potensi risiko rentan menjadi tinggi. Indikator ini dipilih karena mudah menentukan batas kritis (critical threshold) dari populasi Gilman et al. (2014). Hasil penetapan nilai batasan dan skor parameter untuk analisis Produktivity-Suscepability Analysis (PSA)-untuk parameter produktivitas ditampilkan pada Tabel 2.

Ikan yang berada di tropic level yang tinggi dan cenderung menetap lebih rentan dari yang bermigrasi. Begitu juga yang tropic levelnya rendah dan tidak bermigrasi lebih rentan lagi (Sanchez dan Barreiro 2014).

\section{Evaluasi Skor Indikator}

Evaluasi skor indikator setiap parameter ikan tembang dan kurisi dilakukan dengan mengumpulkan data yang (primer dan sekunder) dari setiap parameter kajian. Dari setiap parameter tersebut di evaluasi tingkat rataan, simpangan baku dan confidence limit. Dari proses tersebut, akan didapatkan data batas atas, dan bawah, yang selanjutnya dilakukan pengklasifikasi skor yang baru dengan mengikuti formulasi berikut (Walpole 1992)

Skor Produkitivitas $=1, j i k a ; x<\mu-0,5 C L$

Skor Productivitas sedang jika $2=x=(\mu-0,5 C L)-(\mu-0,5 C L)$

Skor Produktivitas tinggi jika $3=x>(\mu>0,5 C L)$

Simbol $\mathrm{X}$ adalah nilai yang diperoleh dari perhitungan, $\mathrm{CL}$ adalah selang kepercayaan (confidence limit) dari data yang dikumpulkan. Parameter suceptability tidak dilakukan review karena lebih adaptif dan cenderung berlaku umum. Atribut produktivitas mencirikan parameter biologi dan dinamika populasi stok. Informasi mengenai produksi tahunan, panjang, berat, makanan, kemampun reproduksi, dan distribusi makanan memberikan sumbangan dalam analisis produktivitas.

Tabel 1 Parameter Produktivitas

\begin{tabular}{|c|c|c|c|}
\hline Parameter & Jenis Data & Analysis & Pengumpulan data \\
\hline$R$ (Intrinsic growth) & length frekuensi & Growth Analysis & In-situ \\
\hline Max age & length frekuensi & Length frequency analysis & In-situ \\
\hline Max size & length frekuensi & Length frequency analysis & In-situ \\
\hline k (Growth Coefficient) & length frekuensi & Von Bartalanfy Plot & In-situ \\
\hline M (Natural Mortality) & length frekuensi & Persamaan empiris Pauly & In-situ \\
\hline Fekunditas & Telur ikan & Gravimetrik dan volumetrik & In-situ and Ex-situ \\
\hline Breeding strategy & Diameter telur & Cohort analysis & In-situ and Ex-situ \\
\hline Recruitmet pattern & Frekuensi Panjang & $\begin{array}{l}\text { Normsep and Gausian } \\
\text { distribution }\end{array}$ & In-situ \\
\hline Age at Maturity & $\begin{array}{l}\text { Panjang dan Diameter } \\
\text { telur }\end{array}$ & Length frequency analysis & In-situ \\
\hline Mean Tropic level & Food habit & $\begin{array}{l}\text { Niche overlap (Simpson and } \\
\text { Jaccard index) }\end{array}$ & In-situ \\
\hline
\end{tabular}


Tabel 2 Parameter dan skor parameter produktivitas

\begin{tabular}{llll}
\hline \multirow{2}{*}{ Atribut Produktivitas } & \multicolumn{2}{c}{ Rangking } \\
\cline { 2 - 4 } & Tinggi (3) & Moderat (2) & Rendah (1) \\
\hline$r$ (pertumbuhan intrinsik) & $>0,5$ & $0,16-0,5$ & $<0,16$ \\
Umur Maksimum & $<10 \mathrm{thn}$ & $10-30 \mathrm{thn}$ & $>30 \mathrm{thn}$ \\
Ukuran Maksimum & $<60 \mathrm{~cm}$ & $60-150 \mathrm{~cm}$ & $150 \mathrm{~cm}$ \\
Bartallanfy koefisien (k) & $>0,25$ & $0,15-0,25$ & $<0,15$ \\
Kematian Alami & $>0,4$ & $0,2-0,4$ & $<0,2$ \\
Fekunditas & $>10^{4}$ butir & $10^{2}-10^{3}$ butir & $<10^{2}$ butir \\
Strategi Pemijahan & 0 & $1-3$ & $>3$ \\
Pola Rekruitment & Keberhasilan dari & Keberhasilan dari & Keberhasilan dari \\
& recruitment tinggi & recruitment & recruitment \\
& $(>75 \%$ dari kelas & moderate $(10-75 \%$ & moderate $(<10 \%$ \\
& tahunan sukses & dari kelas ukuran & dari kelas ukuran \\
Umur Kematangan Gonad & & sukses) & $>4$ th \\
Rata-rata tropic level & $<2$ thn & $2-4$ thn & $>3,5$ \\
\hline
\end{tabular}

Sumber: Patrick, (2009)

\begin{tabular}{|c|c|c|c|c|c|c|c|c|c|c|c|c|c|c|c|}
\hline Parameter & Satuan & $n$ & 1 & 2 & 3 & 4 & 5 & 6 & 7 & 8 & 9 & 10 & 11 & 12 & Rataan \\
\hline SFP & $\mathrm{mm}$ & 6 & 156.1 & 141.4 & 128.2 & 144.6 & 150.2 & 162.8 & & & & & & & 147.20 \\
\hline Lmax & $\mathrm{mm}$ & 6 & 200.0 & 185.0 & 165.0 & 170.0 & 154.0 & 178.0 & & & & & & t & 175.33 \\
\hline K & tahun & 10 & 0.5 & 0.4 & 0.6 & 0.6 & 0.3 & 0.3 & 1.5 & 1.6 & 1.1 & 0.7 & & & 0.75 \\
\hline to & & 6 & -0.2 & -0.3 & -0.3 & -0.3 & -0.4 & -0.4 & & & & & & & -0.31 \\
\hline Lœ & $\mathrm{mm}$ & 8 & 189.1 & 191.7 & 183.2 & 190.5 & 181.9 & 170.2 & 204.3 & 237.6 & & & & & 193.56 \\
\hline b & & 11 & 3.3 & 2.3 & 2.9 & 2.7 & 2.1 & 3.0 & 3.0 & 2.6 & 2.2 & 2.6 & 2.8 & & 2.68 \\
\hline M & & 7 & 0.6 & 0.5 & 0.7 & 1.1 & 2.0 & 1.6 & 0.9 & & & & & & 1.05 \\
\hline $\mathrm{F}$ & & 7 & 1.0 & 0.8 & 0.4 & 7.4 & 4.6 & 2.9 & 0.7 & & & & & & 2.53 \\
\hline umur max & tahun & 5 & 0.6 & 0.5 & 1.1 & 0.9 & 1.7 & & & & & & & & 0.96 \\
\hline Fekunditas & butir & 8 & 9691.0 & 173335.0 & 1848.0 & 13506.0 & 8251.0 & 294500.0 & 1580.0 & 11947.0 & & & & & 64332.25 \\
\hline $\mathrm{Lm}$ & $\mathrm{mm}$ & 12 & 161.0 & 170.0 & 150.0 & 168.3 & 155.0 & 179,4 & 192,4 & 163.0 & 155.0 & 116.0 & 133.0 & 144.0 & 151.53 \\
\hline $\begin{array}{l}\text { pertumbuhan } \\
\text { intrinsik }\end{array}$ & $\mathrm{kg} /$ tahun & 3 & 2.3 & 3.0 & 10.5 & & & & & & & & & & 5.25 \\
\hline rekrutmen & $\%$ & 4 & 29.2 & 16.8 & 18.5 & 14.4 & & & & & & & & & 19.71 \\
\hline $\mathrm{F} / \mathrm{M}$ & & 7 & 1.7 & 1.6 & 0.5 & 6.4 & 2.3 & 1.8 & 0.8 & & & & & & 2.18 \\
\hline
\end{tabular}

\section{HASIL}

\section{Parameter Productivitas Ikan Tembang}

Evaluasi atribut produktivitas dari ikan tembang meliputi evaluasi parameter rata-rata sebaran frekuensi panjang (SFP), panjang maksimum, koefisien pertumbuhan, to, panjang tak hingga, koefisien panjang berat, mortalitas, fishing teknologi, umur maksimum, fekunditas, panjang matang gonad, pertumbuhan intrinsik vulnerability (Cheung 2008), persen recruitment, rasio F/M. Kerentanan ekologi dan biologi dapat direduksi dengan pembatasan alat penangkapan, hasil tangkap dan peningkatan efektivitas pengelolaan Schulte et al. (2015). Evaluasi dari 11 data riset terkait ikan tembang disajikan pada Tabel 3.

Nilai dari setiap parameter tersebut, kemudian dianalisis nilai tengah dan confidence interval. Dalam upaya melakukan evaluasi, maka indikator nilai minimum, maksimum, dan nilai tengah penting untuk ditampilkan sebagai dasar perhitungan. Hasil perhitungan nilai setiap para- meter tersebut disajikan pada Tabel 4.

\section{Nilai Indikator Ikan Kurisi}

Pengelompokkan data ikan kurisi dilakukan setelah melakukan pengkajian dari data ikan kurisi yang diperoleh dari Labuan dan Karangantu. Ikan demersal memiliki keunikan sebagai biota yang tidak melakukan migrasi dalam jarak yang jauh. Ikan ini umum tergolong kelompok ikan demersal kecil memiliki habitat pada karang. Namun demikian risiko dari tingginya permintaan akan berdampak pada peningkatan produksi dan penggunaan alat tangkap yang berada. Hasil dari evaluasi data terhadap nilai atribut produktivitas kelompok ikan yang diperlukan disajikan pada Tabel 5.

Parameter produktivitas ikan kurisi yang dianalisis sebanyak 11 parameter, dengan jumlah data yang tersedia antara 3-17 data. Semua data ditentukan nilai minimum, nilai maksimum, nilai tengah dan confidence intervalnya. Data tersebut disajikan pada Tabel 6. 
Tabel 3 Data setiap paremeter yang dianalisis ikan tembang

\begin{tabular}{|c|c|c|c|c|c|c|c|c|c|c|c|c|c|c|c|}
\hline Parameter & Satuan & $\mathbf{n}$ & 1 & 2 & 3 & 4 & 5 & 6 & 7 & 8 & 9 & 10 & 11 & 12 & Rataan \\
\hline SFP & $\mathrm{Mm}$ & 6 & 156,12 & 141,38 & 128,16 & 144,56 & 150,19 & 167,78 & & & & & & & 147,19 \\
\hline Lmax & $\mathrm{Mm}$ & 6 & 200 & 185 & 165 & 170 & 154 & 178 & & & & & & & 175,33 \\
\hline $\mathrm{K}$ & tahun & 10 & 0,48 & 0,39 & 0,59 & 0,55 & 0,26 & 0,33 & 1,48 & 1,6 & 1,07 & 0,71 & & & 0,74 \\
\hline to & & 6 & $-0,203$ & $-0,25$ & $-0,32$ & $-0,31$ & $-0,38$ & $-0,4$ & & & & & & & $-0,310$ \\
\hline Lœ & $\mathrm{mm}$ & 8 & 189,07 & 191,65 & 183,22 & 190,45 & 181,94 & 170,23 & 204,3 & 237,6 & & & & & 193,55 \\
\hline b & & 11 & 3,34 & 2,28 & 2,92 & 2,66 & 2,09 & 2,99 & 2,97 & 2,55 & 2,22 & 2,63 & 2,75 & & 2,67 \\
\hline M & /tahun & 7 & 0,55 & 0,48 & 0,73 & 1,146 & 1,995 & 1,58 & 0,89 & & & & & & 1,0 \\
\hline$F$ & /tahun & 7 & 0,96 & 0,79 & 0,36 & 7,376 & 4,634 & 2,86 & 0,7362 & & & & & & 2,53 \\
\hline umur max & tahun & 5 & 0,57 & 0,53 & 1,08 & 0,92 & 1,7 & & & & & & & & 0,96 \\
\hline Fekunditas & butir & 8 & 9691 & 173335 & 1848 & 13506 & 8251 & 294500 & 1580 & 11947 & & & & & 64332 \\
\hline $\mathrm{Lm}$ & $\mathrm{mm}$ & 12 & 161 & 170 & 150 & 168,3 & 155 & 179,4 & 192,4 & 163 & 155 & 116 & 133 & 144 & 151,53 \\
\hline \multicolumn{16}{|l|}{ pertumbuhan } \\
\hline rekrutmen & $\%$ & 4 & 29,19 & 16,83 & 18,46 & 14,36 & & & & & & & & & 19,71 \\
\hline $\mathrm{F} / \mathrm{M}$ & & 7 & 1,74 & 1,64 & 0,49 & 6,43 & 2,32 & 1,81 & 0,82 & & & & & & 2,18 \\
\hline
\end{tabular}

Keterangan: SFP=sebaran frekuensi panjang; Lmax =panjang maksimum; $\mathrm{k}=$ koefisien pertumbuhan panjang; $\mathrm{t}_{\mathrm{o}}=$ panjang waktu umur nol; $L_{\infty}=$ panjang tak hingga; $b=$ koefisien pertumbuhan panjang bobot; $M=$ mortalitas alami; $F=m o r t a l i t a s$ fishing; $\mathrm{Lm}=$ panjang saat matang gonad; $\mathrm{F} / \mathrm{M}=$ rasio mortalitas fishing terhadap mortalitas alami; $\mathrm{n}=$ jumlah data yang dianalisis dengan nomor 1-12. Rataan= adalah rata-rata dari nilai setiap parameter.

Tabel 4 Range nilai produktivitas ikan tembang

\begin{tabular}{llrrr}
\hline Parameter & Satuan & Min & Max & Rataan \\
\hline SFP & mm & 128,2 & 162,78 & $147,2 \pm 12,1$ \\
Lmax & mm & 154,0 & 200,00 & $175,3 \pm 16,12$ \\
K & tahun & 0,3 & 1,60 & $0,7 \pm 0,48$ \\
To & & $-0,4$ & $-0,20$ & $-0,3 \pm 0,07$ \\
Lo & mm & 170,2 & 237,60 & $193,6 \pm 20,26$ \\
B & & 2,1 & 3,34 & $2,7 \pm 0,38$ \\
M & & 0,5 & 2,00 & $1,1 \pm 0,56$ \\
F & 0,4 & 7,38 & $2,5 \pm 2,63$ \\
umur max & tahun & 0,5 & 1,70 & $1,0 \pm 0,471)$ \\
Fekunditas & butir & 1580,0 & 294500,00 & $64332,3 \pm 109648,28$ \\
Lm & mm & 116,0 & 170,00 & $1515 \pm 16,77$ \\
Pertumbuhan & & & 10,46 & $5,2 \pm 4,531)$ \\
intrinsik & kg/tahun & 2,3 & 29,19 & $19,7 \pm 6,54$ \\
rekrutmen & \% & 14,4 & 6,44 & $2,2 \pm 1,96$ \\
F/M & & 0,5 & & \\
\hline
\end{tabular}

Keterangan : SFP = selang frekuensi panjang; $\mathrm{L} \infty=$ panjang infinity ; to = umur ikan pada waktu panjang nol; $\mathrm{F}=$ mortalitas penangkapan $; \mathrm{M}=$ mortalitas alami; $\mathrm{K}=$ koefisien pertumbuhan $; \mathrm{CL}=$ confidence limit (pada SK 95\%). 1)= www. Fishbase.

Tabel 5 Data setiap paremeter yang dianalisis

\begin{tabular}{|c|c|c|c|c|c|c|c|c|c|c|c|}
\hline Parameter & SFP & $L \max$ & $K$ & to & $\begin{array}{c}L œ \\
(m m)\end{array}$ & $b$ & $M$ & $\boldsymbol{F}$ & Fekunditas & $L m$ & $F / M$ \\
\hline Satuan & $\mathrm{mm}$ & $\mathrm{mm}$ & $\begin{array}{c}\text { Per } \\
\text { tahun }\end{array}$ & $\mathbf{m m}$ & $\begin{array}{c}\text { Per } \\
\text { tahun }\end{array}$ & & $\begin{array}{c}\text { Per } \\
\text { tahun }\end{array}$ & $\begin{array}{c}\text { Per } \\
\text { tahun }\end{array}$ & butir & $\mathrm{mm}$ & $\%$ \\
\hline $\mathbf{n}$ & 17 & 17 & 10 & 8 & 8 & 6 & 8 & 8 & 4 & 3 & 8 \\
\hline 1 & 141,3 & 172,2 & 0,1 & $-0,7$ & 224,9 & 2,2 & 0,2 & 0,3 & 25,1 & 213,0 & 1,1 \\
\hline 2 & 132,9 & 139,5 & 0,2 & $-0,5$ & 211,9 & 2,3 & 0,3 & 0,3 & 170,9 & 233,0 & 1,0 \\
\hline 3 & 158,2 & 164,0 & 0,5 & $-1,9$ & 217,5 & 1,8 & 0,5 & 0,7 & 1139,0 & 170,0 & 1,3 \\
\hline 4 & 152,4 & 168,6 & 0,3 & $-1,1$ & 282,1 & 1,8 & 0,2 & 1,1 & 63727,0 & & 4,4 \\
\hline 5 & 160,0 & 235,9 & 0,4 & $-0,2$ & 334,3 & 2,8 & 0,3 & 0,7 & & & 2,2 \\
\hline 6 & 124,4 & 151,3 & 0,2 & $-0,5$ & 493,4 & 2,9 & 0,4 & 2,0 & & & 4,6 \\
\hline 7 & 159,0 & 129,4 & 0,2 & $-2,5$ & 323,0 & & 0,9 & 1,7 & & & 1,9 \\
\hline 8 & 138,7 & 182,0 & 0,3 & $-1,7$ & 319,8 & & 0,7 & 0,6 & & & 0,8 \\
\hline 9 & 149,9 & 181,3 & 0,8 & & & & & & & & \\
\hline 10 & 182,1 & 237,1 & 0,6 & & & & & & & & \\
\hline 11 & 131,3 & 279,5 & & & & & & & & & \\
\hline 12 & 133,0 & 221,8 & & & & & & & & & \\
\hline 13 & 148,2 & 287,5 & & & & & & & & & \\
\hline 14 & 215,5 & 322,5 & & & & & & & & & \\
\hline 15 & 1539 & 152,5 & & & & & & & & & \\
\hline 16 & 165,7 & 173,4 & & & & & & & & & \\
\hline 17 & 105,7 & 205,9 & & & & & & & & & \\
\hline Rataan & 175,19 & 243,00 & 0,36 & $-1,14$ & 300,86 & 2,29 & 0,45 & 0,90 & 16265,49 & 205,33 & 2,16 \\
\hline
\end{tabular}


Keterangan: SFP=Standar frekuensi panjang; Lmax =panjang maksimum; $\mathrm{k}=$ koefisien pertumbuhan panjang; $t_{0}=$ panjang waktu umur nol; $L_{\infty}=$ panjang tak hingga; $b=$ koefisien pertumbuhan panjang bobot; $M=$ mortalitas alami; $F=$ mortalitas fishing; $\mathrm{Lm}=$ panjang maksimum; $\mathrm{F} / \mathrm{M}=$ rasio mortalitas fishing terhadap mortalitas alami.

Tabel 6 Range nilai produktivitas ikan kurisi

\begin{tabular}{llrrr}
\hline Kriteria & Satuan & Min & Max & Rataan \\
\hline SFP & mm & 105,7 & 215,49 & $150,12 \pm 24,48$ \\
Lmax & mm & 129,4 & 322,50 & $200,26 \pm 55,84$ \\
K & tahun & 0,1 & 0,77 & $0,36 \pm 0,21$ \\
to & & $-2,5$ & $-0,22$ & $-1,14 \pm 0,81$ \\
Lø & mm & 211,9 & 493,36 & $300,86 \pm 92,59$ \\
b & & 1,8 & 2,88 & $2,29 \pm 0,45$ \\
M & & 0,2 & 0,89 & $0,45 \pm 0,23$ \\
F & & 0,3 & 1,99 & $0,90 \pm 0,63$ \\
Fekunditas & butir & 25,1 & 63727,00 & $16265,49 \pm 31644,8$ \\
Lm & mm & 170,0 & 233,00 & $205,33 \pm 32,192)$ \\
F/M & & 0,8 & 4,64 & $2,16 \pm 1,52$ \\
\hline
\end{tabular}

Keterangan; SFP = selang frekuensi panjang; $L \infty=$ panjang infinity; to = umur ikan pada waktu panjang nol; $F$ = mortalitas penangkapan; $\mathrm{M}=$ mortalitas alami; $\mathrm{K}=$ koefisien pertumbuhan; $\mathrm{CL}=$ confidences limit (SK 95\%); 2 = Brojo, 2002.

\section{PEMBAHASAN}

\section{Evaluasi Ikan Tembang}

Sardinella sp. dijadikan sebagai salah satu spesies kajian karena dominan (Hofstede and Collas 2006), dikonsumsi dan juga mudah dimonitor (Khlebovich 1997) aspek biologinya. Ikan kecil dan berinteraksi dengan habitat pesisir, biasanya mudah mengalami kerentanan (Franca et al. 2012). Hasil monitor parameter biologi ikan tembang yang lebih tinggi dari standar nilai NOAA yaitu parameter pertumbuhan intrinsik, laju pertumbuhan populasi, mortalitas alami. Sedangkan parameter umur maksimum, ukuran maksimum, recruitment, umur matang gonad dan mean tropic level lebih rendah nilainya. Batasan skor parameter biologi ikan tembang setelah evaluasi sehingga diperoleh nilai batasan yang baru dari yang ditetap oleh NOAA adalah seperti Tabel 7. Analisis indikator berbasis ukuran erat kaitanya dengan kerentanan (Probst et al. 2013). Parameter laju tumbuh ikan Sardinella fimbriata tinggi, namun masih lebih rendah dari jenis Sardinella madarensi mencapai 0,48-1,26/tahun (Gabchea and Hockey 1995) atau $S$ aurita (k=1,2/year) di barat Afrika (Fur dan Simon 2009). Pertumbuhan yang cepat karena habitat yang sesuai (Brehmer et al. 2013) mempercepat pertambahan panjang. Panjang $S$. fimbriata lebih merata dengan panjang maksimum mencapai $18 \mathrm{~cm}$ yang lebih rendah dari panjang maksimum jenis $S$. aurita dari pantai Senegal dengan rata rata 30,6 cm (Diop et al. 2016) dan
S. madarensi ((Gabche and Hockey 1995). Jenis $S$. madarensi mampu mencapai panjang infinite 27,25 cm/tahun (Gabche and Hockey 1995). Fur dan Simon (2009), mendapatkan panjang infiniti $S$ aurita $L_{\infty}$ adalah $30,63 \mathrm{~cm}$ yang lebih tinggi dari $S$ fimbriata yang hanya 20 $\mathrm{cm}$. Umur saat panjang nol dari $S$ aurita yaitu (0,062 ) yang lebih rendah dari $S$ fimbriata di Labuan.

$S$ fimbriata lebih awal mencapai matang gonad (Lm 14,6-15,6 cm), dibandingkan $S$ madarensi yang matang gonad mencapai 19,1 $\mathrm{cm}$ jantan dan 17,43 untuk betina (Gabche and Hockey 1995). $\quad S$ aurita di pantai barat Afrika pertama kali matang pada ukuran $21 \mathrm{~cm}$, dan mengalami 4 masa reproduksi 4 kali setahun. Tingkat fekunditas $S$ fimbrita maksimum 102.320 butir lebih tinggi dari $S$ aurita yang mencapai 45.197 Fur dan Simon (2009). Selanjutnya proses pemijahan $S$ aurita mulai awal summer di Mediteranea (Somarakis et al. 2002). Proses repoduksi $S$ aurita dan $S$ maderensis di pantai Maroko biasanya terjadi saat autum ke winter atau saat bulan Juli dari Juni (Ettahiri et al. 2003). Keberhasilan pemijahan dengan kombinasi temperature mempercepat proses kerentanan (Sirot et al. 2015).

Keberhasilan dan perkembangan telur dan larva Brazilian sardine dipengaruhi oleh kuat tempreature (Moraes et al. 2012). Aktivitas angin, percampuran air dan kondisi air yang relatif homogen secara vertikal juga memberikan pengaruh terhadap kesuksesan 
pemijahan dan rekruitmen (Palomera et al. 2007 dan chlorophyll-a (Sartimbul et al. 2010) serta ketersediaan makanan (Pitchaikani and Lipton 2015).

Tingkat survival dan rekruitmen dari Sardinella brasiliensis berkisar antara 14-70\% dalam setahun (Dias et al. 2014) yang lebih tinggi dari $S$ fimbriata di Labuan. Artinya $S$ fimbriata tingkat survival nya rendah dan tidak mampu bertahan dan tumbuh menjadi individu dewasa. Populasi $S$ fimbriata memerlukan kondisi oceanography yang baik (Zeeberg et al. 2008). Keberhasilan recruitment ditentukan oleh jumlah telur yang besar, dan tingkat kelangsungan hidupnya, yang juga tergantung pada kondisi oceanography, adaptive capacity (Jacinto et al. 2015) serta lamanya transport larva (Sabates et al. 2013). Perubahan musim penangkapan sepuluh tahun terakhir yang makin efisien harusnya dapat meningkatkan rekuitmen (Braham et al. 2014).

Survival yang rendah dapat terjadi karena mortalitas dan penangkapan yang tinggi. Mortalitas alami $S$ fimbriata mencapai 0, 85/thn dan mortalitas penangkapan 3,5/thn. Mortalitas ini tergolong tinggi jika dibandingkan dengan $S$ madarensis yang 0,74/thn dan mortalitas fishing 0,1/thn (Gabche and Hockey 1995) dan hampir sama dengan mortalitas $S$ aurita antara 0,40,9/thn (Fur and Simon 2009). Mortalitas alami jenis $S$ albella dapat meningkatkan karena parasit (Printrakoon and Purivirojkul 2011). Mortalitas penangkapan $S$ aurita yang tinggi akan meningkatkan laju pertumbuhan produksi (intrinsic growth). Laju dari nilai pertumbuhan intrinsik terjadi karena produksi yang cenderung tinggi dengan peningkatan upaya (Wang et al. 2014) dan alat tangkap yang bersifat menangkap multi spesies (Stelzenmuller et al. 2010).

Pertumbuhan $S$ fimbriata yang tergolong cepat juga karena pengaruh dari faktor lingkungan dan makanan. Pertumbuhan dan distribusi larva $S$ aurita sangat terkait dengan distribusi dan komposisi plankton di NW Mediteranean (Morote et al. 2008). Perubahan ukuran juga mempengaruhi perubahan struktur makanan. S. aurita yang berukuran besar dari $17,28 \mathrm{~cm}$ memakan makanan yang lebih besar dan berada pada tropic level lebih atas (Campo et al. 2006). Dalam hubungan dengan tropic level, hubungan makan dan dimakan (predatorprey) juga mempengaruhi kerentanan selain kelompok spesies, geography (landscape) (Alessa et al. 2008), tipe ekosistem (Chessman 2013) termasuk habitat (Cinner et al. 2012).

\section{Evaluasi Ikan Kurisi}

Parameter produktivitas ikan kurisi yang memiliki nilai lebih rendah dari nilai yang ditetapkan NOAA adalah umur maksimum, ukuran maksimum, rekruitmen, umur matang gonad dan mean tropic level. Parameter pertumbuhan intrinsic, laju pertumbuhan populasi, dan mortalitas alami lebih besar dari nilai yang ditetapkan NOAA. Penggunaan parameter life history di Mediteranean juga telah berkembang sejak lama (Osie et al. 2015). Hasil penetapan skor dari nilai tersebut disajikan pada Tabel 8.

Ikan kurisi merupakan ikan demersal yang dapat ditemukan dari kedalaman $10 \mathrm{~m}$ sampai 115 meter (Garces et al. 2006). Kelompok ikan Nemipteridae, termasuk ikan yang berkualitas baik dan banyak dimanfaatkan sebagai produk olahan (Oujifard et al. 2012). Akibatnya ikan ini menjadi salah satu target utama penangkapan (Tobin et al. 2013). Laju tangkapan ikan kurisi (Nemipterus japonicas) di NW Red Sea lebih tinggi siang hari daripada malam hari (Yousif 2003). Ukuran ikan yang tertangkap dengan panjang total $12 \mathrm{~cm}$ siang, dan $22 \mathrm{~cm}$ malam hari dengan rata rata 15,4 \pm $2,387 \mathrm{~cm}$ siang dan 16,0 $\pm 2,949 \mathrm{~cm}$. Secara umum ikan Nemipterus sp yang kecil lebih aktif siang hari dan ukuran besar lebih dominan aktif siang hari.

Kelompok Nemipteridae di Western Australia tertangkap dengan ukuran $5-20 \mathrm{~cm}$ (Wakefield et al. 2007) dan panjang kelompok dominan tertangkap di NE Mediteranean yaitu 8,5, 14 dan $20 \mathrm{~cm}$ (Özbilgin et al. 2015). Ukuran ini hampir sama dengan tangkapan Nemipterus sp. di Labuan dengan rata rata 15,8 $\mathrm{cm}$ dengan panjang maksimum $20 \mathrm{~cm}$. Panjang total ikan $N$ japonicus di Red Sea antara 9,923,2 cm ElHaweet (2013)

Laju pertumbuhan ikan kurisi di Labuan antara 0,2-0,4 tergolong cepat dibandingkan $N$ japonicas dari Red Sea yang mencapai $(\mathrm{k}=0,18)$ ElHaweet (2013) kofisien panjang berat antara 2,1 sampai 2,7 yang menunjukan ikan relatif kurus juga rendah dari Nemipterus japonicas di Red Sea dengan koefisien hubungan panjang berat 3,206 ElHaweet (2013). Termasuk ikan yang lambat tumbuh dengan panjang awal waktu umur nol tahun sebesar $(-0,55)$ ElHaweet (2013). Ikan yang lambat tumbuh dan ukuran kecil sangat rentan terhadap penangkapan (Fromentinau and Fonteneau 2001).

Ikan kurisi mulai matang gonad pada ukuran $18 \mathrm{~cm}$, dan maksimal pada ukuran 22,3 
cm. Sebagai kelompok ikan demersal $N$ japonicas, dominan didaerah pesisir yang erat kaitanya dengan produktivitas biologi (Seixas et al. 2015). Mulai banyak tertangkap selama Januari sampai April dan juga Oktober sampai December (MPEDA 1994) in Jeevanandam et al (2001). Biasanya nelayan mulai mengarahkan penangkapan pada kelompok ikan ini yang menyebabkan mortalitas fishing meningkat.

Mortalitas penangkapan ikan kurisi di Labuhan antara 0,6-1,2/tahun tergolongg tinggi, sementara mortalitas alami hanya 0,5/tahun. Jika dibandingkan dengan mortalitas alami Nemipterus sp dari Western Australia sebesar ( $\mathrm{M}=2,58$ /tahun) (Wakefield et al. 2007), maka sesungguhnya ikan di Labuan lebih mampu survive dengan baik. Tingkat mortalitas dan reproduksi lebih signifikan dipengaruhi oleh panjang ikan dari ukuran (Catalano and Allen 2013).

Peningkatan produksi kurisi karena peningkatan permintaan dari jenis ini terutama di Thailand sampai tahun 2012 yang mencapai 100.000 MT per tahun untuk kebutuhan surimi (Wiriyaphan 2015) dan gelatin (Koli et al. 2012). Rasio eksploitasi ikan Nemipterus sp di Thailand, Malaysia dan Philipina sejak tahun 1971 sampai tahun 1995 terus menunjukkan peningkatan bahkan lebih dari $90 \%$ yang tergolong over eksploitasi (Stobutzki et al. 2006). Namun efek ekonomi secara tidak langsung berdampak terhadap status stok (Agundez 2014).

Dari parameter produktivitas di atas, tingkat nilai dari parameter ikan tembang dan kurisi secara bersamaan berbeda. Ukuran maksimum ikan tembang dan kurisi jauh lebih rendah dari ikan pelagis besar yan ditetapkan NOAA dalam Patrick (2009). Begitu juga umur maksimum dan panjang saat matang gonad. Untuk parameter laju tumbuh, mortalitas, intrinsic growth dan rekruitmen ikan pelagis dan demersal lebih tinggi dari batasan NOAA seperti tampilan gambar berikut.

Menurut Sadovy (2003) kelompok ikan kecil (pelagis dan demersal) termasuk yang rentan terhadap tekanan, dan mudah mengalami penurunan biomass dan kelimpahan (Fenner 2014). Ikan pelagis besar cenderung melakukan migrasi dengan cepat dalam rentang ecology yang luas dan cepat mendapatkan makanan "food supply" (Millner 2007), sehingga dapat tumbuh lebih lama.

Sebagai kelompok ikan yang secara morfologi, biologi berbeda dengan pelagis besar, evaluasi ini penting untuk menentukan batasan tingkat kerentanan yang lebih tepat. Dengan batasan yang ditetapkan oleh NOAA (2009) kelompok ikan kecil (pelagis dan demersal) tergolong tidak rentan, karena selalu berada pada selang indikator minimum. Padahal pada prakteknya sudah terjadi kondisi biologi dan teknologi over fishing dan penurunan ukuran produksi. Menurut Yonvitner et al. (2013) sebagian besar ikan kecil (pelagis dan demersal) terlihat tidak pernah dalam kondisi rentan dengan pendekatan NOAA. Selain itu juga diperlukan pengembangan dari indikator spesies seperti laju tangkap, proporsi hasil tangkapan, mortalitas alami, dan nilai maksimum tangkap lestari (Pitcher 2014). Pengelolaan perikanan harus hati-hati dalam menginterpretasikan perubahan nilai PSA ketika stok akan dievaluasi (Ormset and Spencer 2011). Pendugaan terhadap kerentanan diutamakan untuk mengembangkan aksi pengelolaan pada level spesies (Manauag et al. 2013) dan menjaga keseimbangan konservasi dan expliotasi (Kalokoski et al. 2010) sehingga berkelanjutan.

Tabel 7 Hasil Evaluasi nilai parameter produktivitas ikan tembang tiap kategori

\begin{tabular}{|c|c|c|c|c|}
\hline \multirow{2}{*}{ Atribute } & \multirow{2}{*}{ Satuan } & \multicolumn{3}{|c|}{ Rangking } \\
\hline & & Rendah (1) & Moderate (2) & Tinggi (3) \\
\hline SFP & $\mathrm{mm}$ & 142,35 & $142,35<x<152,05$ & 152,05 \\
\hline $\mathrm{L}_{\max }$ & $\mathrm{mm}^{\mathrm{a})}$ & 168,88 & $168,88<x<181,78$ & 181,78 \\
\hline $\mathrm{K}$ & $/$ tahun $^{\text {b) }}$ & 0,60 & $0,60<x<0,89$ & 0,89 \\
\hline$t_{0}$ & & $-0,34$ & $-0,34<x<-0,28$ & $-0,28$ \\
\hline Lœ & $\mathrm{mm}$ & 186,54 & $186,54<x<200,58$ & 200,58 \\
\hline B & & 2,57 & $2,57<x<2,79$ & 2,79 \\
\hline$M$ & /tahun b) & 1,26 & $0,85<x<1,26$ & 0,85 \\
\hline $\mathrm{F}$ & /tahun ${ }^{\text {b) }}$ & 3,50 & $1,56<x<3,50$ & 1,56 \\
\hline Umur max & tahun $^{\text {a) }}$ & 0,75 & $0,75<x<1,17$ & 1,17 \\
\hline Fekunditas & butira) $^{\text {a }}$ & 26341,76 & $26341,76<x<102322,74$ & 102322,74 \\
\hline & $\mathrm{mm}$ & 146,78 & $146,78<x<156,28$ & 156,28 \\
\hline \multicolumn{5}{|l|}{ Pertumbuhan } \\
\hline intrinsic $(r)$ & $\mathrm{kg} /$ tahun $^{\text {b) }}$ & 2,69 & $2,69<x<$ & 7,81 \\
\hline Rekrutmen & $\%$ & 16,51 & $16,51<x<22,91$ & 22,91 \\
\hline F/M & & 2,91 & $1,46<x<2,91$ & 1,45 \\
\hline
\end{tabular}

Ket: ${ }^{a}$ berwarna hijau lebih rendah dari batasan nilai NOAA; ${ }^{\text {b) }}$ Berwarna merah yang berarti lebih tinggi dari batasan nilai NOAA. 
Tabel 8 Hasil Evaluasi nilai parameter produktivitas ikan kurisi tiap kategori

\begin{tabular}{|c|c|c|c|c|}
\hline \multirow{2}{*}{ Kriteria } & \multirow{2}{*}{ Satuan } & \multicolumn{3}{|c|}{ Rangking } \\
\hline & & Rendah (1) & Moderate (2) & Tinggi (3) \\
\hline SFP & $\mathrm{Mm}$ & 166,87 & $166,87<x<183,51$ & 183,51 \\
\hline$L_{\max }$ & $\mathrm{mm}^{\mathrm{a})}$ & 100,57 & $100,57<x<385,45$ & 385,43 \\
\hline $\mathrm{K}$ & Tahun b) & 0,30 & $0,30<x<0,42$ & 0,42 \\
\hline to & $\mathrm{Mm}$ & $-1,42$ & $-1,42<x<-0,86$ & $-0,86$ \\
\hline$L_{\infty}$ & $\mathrm{Mm}$ & 268,77 & $268,77<x<332,94$ & 332,94 \\
\hline $\mathrm{b}$ & & 2,11 & $2,11<x<2,47$ & 2,47 \\
\hline$M$ & /tahun'b) & 0,37 & $0,37<x<0,53$ & 0,53 \\
\hline $\mathrm{F}$ & /tahun $\left.{ }^{\mathrm{b}}\right)$ & 0,68 & $0,68<x<1,12$ & 1,12 \\
\hline Fekunditas & Butir a) & 75979 & $759,79<x<31771,19$ & 31771,19 \\
\hline Lmature & $\mathrm{Mm}$ a) & 187,12 & $187,12<x<223,55$ & 223,55 \\
\hline $\mathrm{F} / \mathrm{M}$ & & 1,63 & $1,63<x<2,69$ & 2,69 \\
\hline
\end{tabular}

Ket: a) berwarna hijau lebih rendah dari batasan nilai NOAA; b) Berwarna merah yang berarti lebih tinggi dari batasan nilai NOAA.
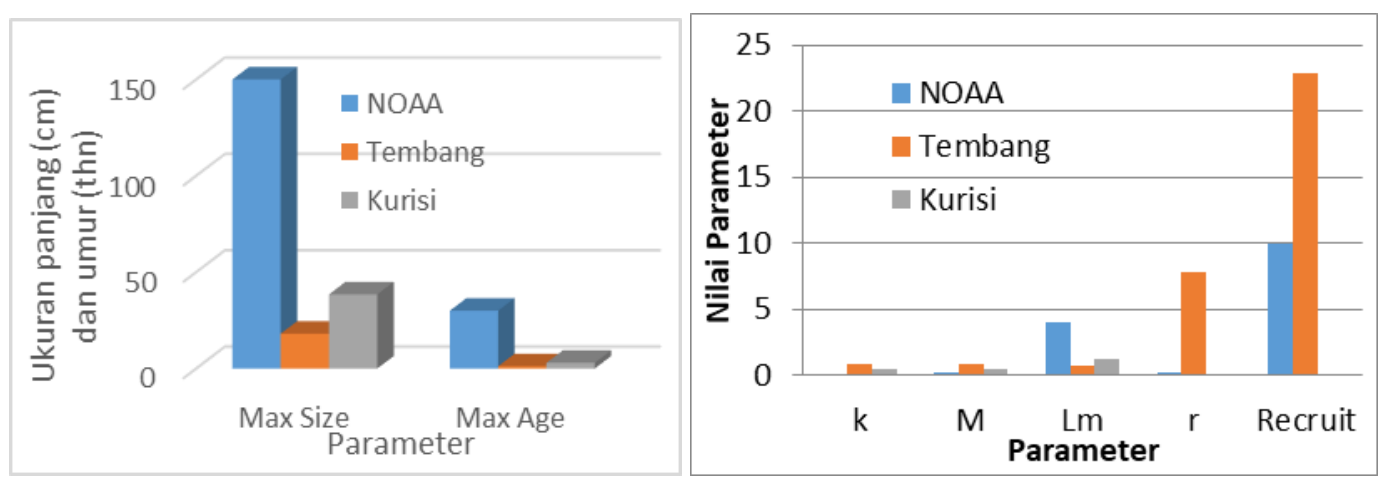

Gambar 1 Perbandingan atribut produktivitas pelagis besar (NOAA dalam Patrick, 2009) dengan produktivitas pelagis kecil (penelitian ini)

\section{KESIMPULAN}

Parameter yang diperbandingkan antara pelagis besar dan pelagis kecil yaitu ikan tembang setidaknya terdapat 6 parameter yang tidak sesuai, dan ikan demersal yaitu ikan kurisi sebanyak 5 parameter yang tidak sesuai dengan batasan NOAA dan akan selalu berada di kisaran nilai tidak berisiko.

Evaluasi beberapa parameter produktivitas ikan pelagis kecil menunjukan nilai batasan yang lebih sempit dibandingkan dengan ikan pelagis besar, sehingga diperoleh batasan nilai kisaran yang juga sempit. Kondisi ini juga menjadi petunjuk bahwa kondisi ikan pelagis kecil dan demersal kecil berpeluang dan rentan terhadap penangkapan.

Penggunaan statistik setidaknya membantu memberikan opsi nilai batasan yang lebih tepat dari data data yang tersedia untuk kelompok ikan pelagis dan demersal.

\section{SARAN}

Dengan memperhatikan syarat minimum evaluasi nilai rataan dan nilai tengah akan lebih baik jika jumlah data setiap parameter jumlahnya sama. Kondisi ini tentu dapat ditutupi dengan penelitian yang sama dalam rentang waktu yang lebih panjang. Kemudian basis data yang digunakan adalah data spesies, maka sebaiknya penggunaan bagi spesies yang baik dari genus, family atau karakter yang sama sehingg lebih adaptif jika diaplikasikan dalam kelompok yang lebih umum seperti dalam satuan genus atau family.

\section{UCAPAN TERIMA KASIH}

Ucapan terima kasih disampaikan kepada tim WWF-Indonesia yang telah memberikan kepercayaan untuk melakukan penelitian ini pada kelompok pelagis besar, sehingga dapat memahami adanya perbedaan dengan ikan pelagis kecil. Selanjutnya kepada $\mathrm{Dr}$ Isdradjad Setyobudiandi, Dr Achmad Fachrudin, Dr Ridwan Affandi, Dr Etty Riani, dan pihak lainnya. Selanjutnya juga menyam- 
paikan terima kasih kepada tim riset Labuan dan Karangantu Simarmata, Megawati, Sari AP, Conny PL, Syakila, Shelvinawati, Purnamawati, Wagiantoro, Cresidanto, Oktaviani, Rahayu ES dan Gumilar atas kerjasamanya.

\section{DAFTAR PUSTAKA}

Agundez JAP, E Yimam, P Raux, HR Vallete, $S$ Girard. 2014. Modelling Economic Vulnerability. As Applied to Microbiological Contaminant on the Thau Lagoon Shellfish Farming Industri. Marine Policy Journal, Elsevier. 46: 143151.

Brojo M, Sari RP. 2002. Biologi Reproduksi Ikan Kurisi (Nemipterus tambuloides Blkr. yang Didaratkan di Tempat Pelelangan Ikan Labuan, Pandeglang. Jurnal iktiologi Indonesia. 2(1): 17-21.

Braham CB, P Fréon, A Laurec, H Demarca, N Bez. 2014. New insights in the Spatial Dynamics of Sardinella Stocks Off Mauritania (North-West Africa) Based on Logbook Data Analysis. Fisheries Research Journal, Elsevier. 154(2014): 195-204.

Brehmer T, T Laugier, J Kantoussan, $\mathrm{F}$ Galgani, D. Mouillot. 2013. Does Coastal Lagoon Habitat Quality Affect fish Growth Rate and Their Recruitment? Insights from Fishing and Acoustic Surveys. Estuarine, Coastal and Shelf Science Journal, Elsevier. 126(2013): 1-6.

Catalano MJ, and MS Allen. 2013. A Size and Age-Structured Model to Estimate fish Recruitment, Growth, Mortality, and Gear Selectivity. Fisheries Research Journal, Elsevier. 105(2013): 38-45.

Campo D, E Mostarda, L Castriota, MP Scarabello, F Andaloro. 2006. Feeding Habits of the Atlantic Bonito, Sarda sarda (Bloch, 1793) in the Southern Tyrrhenian Sea. Fisheries Research Journal, Elsevier. 81(2006): 169-175.

Cheung WWL, TJ Pitcher, D Pauly. 2005. A Fuzzy Logic Expet System to Estimate Intrinsic Extinction Vulnerability of Marine Fishes to Fishing. Biological Conservation Journal, Elsevier. 124(2005): 97-111.

Cheung WWL, TJ Pitcher. 2008. Evaluating the Status of Exploited Taxa in the Northern South Chian Sea Using Intrinsic Vulnerability and Spatial Explicit Catch
Per Unit Effort Data. Fisheries Research, Elsevier. 92(2008): 28-40.

Chessman BC. 2013. Identifying Species at Risk from Climate Change: Traits Predict the Drought Vulnerability of Freshwater Fishes. Biological Conservation Journal, Elsevier. 160(2013): 40-49.

Cinner JF, TR Mc Clanahan, NAJ Graham, TM Daw, J Maina, SM Stead. A Wamukota, K Brown, O Bodin. 2012. Vulnerability of Coastal Community to Key Impact of Climate Change on Coral Reef Fisheries. Global Environemntal Change Journal, Elsevier. 22(2013): 12-20.

Diop M, M Howsam, C Diopb, F Cazier, JF Goossens, A Diouf, R Amaraa. 2016. Spatial and Seasonal Variations of Trace Elements Concentrations in Liver and Muscle of Round Sardinelle (Sardinella aurita) and Senegalese Sole (Solea senegalensis) Along the Senegalese Coast. Chemosphere Journal, Elsevier. 144(2016): 758-766.

Dias DF, LP Pezzi, DFM Gherardi, R Camargo. 2014. Modeling the Spawning Strategies and Larval Survival of the Brazilian Sardine (Sardinella brasiliensis). Progress in Oceanography Journal, Elsevier. 123(2014): 38-53.

ElHaweet, AEA, 2013. Biological Studies of the Invasive Species Nemipterus japonicus (Bloch, 1791) as a Red Sea Immigrant into the Mediterranean. Egyptian Journal of Aquatic Research, Elsevier. (2013)39: 267-274.

Ettahiri O, Am Berraho, G Vidy, M Ramdani, T Dochi. 2003. Observation on the Spawning of Sardina and Sardinella off the South Moroccan Atlantic Coast (21$\left.26^{\circ} \mathrm{N}\right)$. Fisheries Research Journal, Elsevier. 60(2003): 207-222.

Fenner D. 2014. Fishing Down the Largest Coral Reef fish Species. Marine Pollution Bulletin Journal, Elsevier. 84(2014): 916.

Franca S, RP Va Vasconcelos, PR Santos, VF Fonseca, MJ Costa, HN Cabral. 2012. Vulnerability of Portuguese Estuary Habitat, to Human Impact and Relationship with Strucutural and Fungsional. Properties of the Fish Community. Ecological Indicator Journal, Elsevier. 18(2012): 11-19.

Fur JL, P Simon. 2009. A New Hypothesis Concerning the Nature of Small Pelagic fish Clusters an Individual-Based 
Modelling Study of Sardinella aurita Dynamics Off West Africa. Ecological Modelling Journal, Elsevier. 220(2009): 1291-1304.

Gabchea CE, Hockey UP. 1995. Growth, Mortality and Reproduction of Sardinella maderensis (Lowe, 1841). In the Artisanal Fisheries Off Kribi, Cameroon. Fisheries Research Journal, Elsevier. 24(1995): 331-344.

Gerasmio IRP, AB Agmata, MD Santos. 2015. Genetic Diversity, Population Genetic Structure, and Demographic History of Auxis thazard (Perciformes), Selar crumenophthalmus (Perciformes), Rastrelliger kanagurta (Perciformes) and Sardinella lemuru (Clupeiformes) in Sulu-Celebes Sea Inferred by Mitochondrial DNA Sequences. Fisheries Research Journal, Elsevier. 162(2015): 64-74.

Gilman E, M Owens, T Kafft. 2014. Ecological Risk Assesent of the Marshall Island Longline Tuna Fishery. Marin Policy Journal, Elsevier. 44(2014): 239-255.

Garces LR, I Stobutzki, M Alias, W Campos, N Koongchai, L-Alino, G Mustafa, S Nurhakim, M Srinath, G Silvestre. 2006. Spatial Structure of Demersal fish Assemblages in South and Southeast Asia and Implications for fisheries Management. Fisheries Research Journal, Elsevier. 78(2006): 143-157.

Hofstede R, MD Collas. 2006. An Investigation of Seasonal and Annual Catches and Discards of the Dutch Pelagic FreezerTrawlers in Mauritania, Northwest Africa. Fisheries Research Journal, Elsevier. 77(2006): 184-191.

Jeevanandam K, A Kakatkar, SN Doke, DR Bongirwar, V Venugopal. 2001. Influence of Salting and Gamma Irradiation on the Shelf-Life Extension of Threadfin Bream in Ice. Food Research International Journal, Elsevier. 34(2001): 739-746.

Jacinto MR, AJG Sangcuan, GV Yip, MD Santos. 2015. Development and Application of the Fisheries Vulnerability Assesement Tool (Fish Tool) to Tuna and Sardine Sector in the Philipines. Fisheries Research Journal, Elsevier. 161(2015): 174-181.

Kalikoski DC, PQ Neto, T Almudi. 2010. Building Adaptive Capacity to Climate Variability: The Case of Artisanal
Fisheries in the Estuary of the Patos Lagoon, Brazil. Marine Policy Journal, Elsevier. 34(2010): 742-751.

Koli, JM, S Basu, BB. Nayak, SB. Patange, A U Pagarkar, V Gudipati. 2012. Functional Characteristics of Gelatin Extracted from Skin and Bone of Tiger-Toothed Croaker (Otolithes ruber) and Pink Perch (Nemipterus japonicus). Food and Bioproducts Processing Journal, Elsevier. 90(2012): 555-562.

Khlebovich VV. 1997. Selection and Criteria for Biological Indicator Species for Arctic Monitoring. Marine Pollution Bull, tm, Elsevier. 35(7): 381-383.

Luna HNM, PT-Boyer, MM Baez. 2014. Social Indicator of Vulnerability for Fishing Community in the Northern Gulf of California. Mexico. Implication for Climate Change. Marine Policy Journal, Elsevier. 45(2014): 192-193.

Manauag SS, PM Alino, RTS Martinez, RN Mualil, MVA Doctor, EC Dizon, RC Geranimo, FM Pang, RB Cabral. 2013. A Framework for Vulnerability Assesement of Coastal Fisheries Ecosystem to Climate Change Tool for Understanding Resilience of Fisheries (VA-NRF). Fisheries Research Journal, Elsevier. 147(2013): 381-393.

Morote E, MP Olivar, F Villate, I Uriarte. 2008. Diet of Round Sardinella, Sardinella aurita Larvae in Relation to Plankton Availability in the NW Mediterranean. Plankton Research Journal. 309(7): 807816.

Moraes LES, DFM Gherardi, M Katsuragawa, ET Paes, 2012. Brazilian Sardine (Sardinella brasiliensis Steindachner, 1879) Spawning and Nursery Habitat: Spatial-Scale Partitioning and Multiscale Relationship with Thermohaline Descriptor. ICES Journal of Marine Science. 69(6): 939-952.

Millner KA. 2007. Climate Variability and Tropical Tuna: Management Challenges for Highly Migratory Fish Stocks. Marine Policy Journal, Elsevier. 31(2007): 5670.

Navas JM, TC Telfen, LG Ross. 2011. Spatial Modelling of Environmental Vulnerability of Marine Finfish Aquaculture using GISBased Neuro Fuzzy Technique. Marine pollution bulletin, Elsevier. 62(2011): 1786-1799. 
Ormseth OA, PP Spencer. 2011. An Assesment of Vulnerability in Alaska groundfish. Fisheries Research Journal, Elsevier. 112(2011): 127-133.

Osie GC, A Orio, CP Miller. 2015. Assesing the Vulnerability of the Mediteranean Demersal Stock and Predicting Exploitation Status of Unassesed Stock. Fisheries Research Journal, Elsevier. 405(2015): 7-12.

Özbilgin H, AR Eryasar, G Gökc, e, Y D Özbilgin, AS Bozaoglu, E Kalecik, B Herrmann. 2015. Size Selectivity of Hand and Machine Woven Codends and Short Term Commercial Loss in the Northeastern Mediterranean. Fisheries Research Journal, Elsevier. 164(2015): 73-85.

Oujifard A, S Benjakul, M Ahmad, J Seyfabadi. 2014. Effect of Bambara Groundnut Protein Isolate on Autolysis and Gel Properties of Surimi from Threadfin Bream (Nemipterus bleekeri). LWT- Food Science and Technology Journal, Elsevier. 47(2012): 261-266.

Patrick WS, P Spencer, O Ormseth, J Cope, J Field, D Kobayashi, T Gedamke, E Cortes, K Bigelow, W Overholtz, J Link, and $P$ Lawson. 2009. Use of Produktivity and Suceptability Indices to Determina Stock Vulnerability, with Example Application to six US Fisheries. NOAA, Technical Memorandum NMFSF/SPO-1-1.

Palomera I, MP Olivar, J. Salat, A. Sabate, M. Coll, A. Garci, B. Morales-Nin. 2007. Small Pelagic Fish in the NW Mediterranean Sea: An Ecological Review. Progress in Oceanography Journal, Elsevier. 74(2007): 377-396.

Pitchaikani SJ and AP Lipton. 2015. Seasonal Variation of Zooplankton and Pelagic Fish Catch in the fishing Grounds Off Tiruchendur Coast, Gulf of Mannar, India. Ecohydrology \& Hydrobiology Journal. 15(2015): 89-100.

Pitcher, CR. 2014. Quantitative Indicators of Environmental Sustainability Risk for a Tropical Shelf Trawl fishery. Fisheries Research Journal, Elsevier. 151(2014): 136-147.

Printrakoon C, W Purivirojkul. 2011. Prevalence of Nerocila Depressa (Isopoda, Cymothoidae) on Sardinella albella from a Thai Estuary. Journal of
Sea Research, Elsevier. 65(2011): 322326.

Probst NK, V Stellzenmuller, G Kraus. 2013. A Simulaton-Approach to Asses the Size Structure of Commerialy Exploited Fish Population within the Europena Marine Strategy Frame Work Direction. Ecological Indicator Journal, Elsevier. 24(2013): 621-632.

Sadovy, Y., Kulbicki, M., Labrosse, P., Letourneur, Y., Lokani, P., Donaldson, T.J., 2003. The Humphead Wrasse, Cheilinus undulatus: Synopsis of a Threatened and Poorly Known Giant Coral Reef fish. Rev. Fish Biol. Fish, Elsevier. 13(2003): 327-364.

Sabatés A, J Salat, V Raya, M Emelianov. 2013. Role of Mesoscale Eddies in Shaping the Spatial Distribution of the Coexisting Engraulis encrasicolus and Sardinella aurita Larvae in the Northwestern Mediterranean. Journal of Marine Systems, Elsevier. 111112(2013): 108-119.

Sanchez FA, TMR Barreiro. 2014. Approaching a Functional Measure of Vulnerability in Marine Ecosystem. Biological indicator, Elsevier. 45(2014): 130-138.

Sartimbul A, H Nakata, E Rohadi, B Yusuf, HP Kadarisman. 2010. Variations in Chlorophyll-a Concentration and the Impact on Sardinella lemuru Catches in Bali Strait, Indonesia. Progress in Oceanography Journal, Elsevier. 87(2010): 168-174.

Schulte DF, P Gorris, W Baitoningsih, DS Adhuri, SCA Ferse. 2015. Coastal Livelihood Vulnerability to Marine Resources Degradation: A Review of the Indonesia National Coastal and Marine Policy Framework. Marine Policy Journal, Elsevier. 52(2015): 163-171.

Seixas, TG, I Moreira, HA Kehrig. 2015. Mercury and Selenium in Seston, Marine Plankton and Fish (Sardinella brasiliensis) as a Tool for Understanding a Tropical Food Web. Marine Pollution Bulletin. 101(2015): 366-369.

Sirot C, S Villeger, D Mouillot, AM Darnaude, JR Miranda, DF Hernandez, J Pantili. 2015. Combination of Biological Atribut Predict Temporal Dynamic of Fish Species in Respons to Environmental Change. Ecological Indicator Journal, Elsevier. 45(2015): 147-156. 
Somarakis S, P Drakopoulus, V Fillipou. 2002. Distribution and Abundance of Larva Fish in the Northern Aegean Sea-Eastern Mediteranean in Relation to Early Summer Oceanogrpahic Condition. Journal of Plantkon Research. 24(4): 339-357.

Stobutzki IC, GT Silvestre, AA Talib, A Krongprom, M Supongpan, P Khemakorn, N Armada, LR Garces. 2006. Decline of Demersal Coastal fisheries Resources in Three Developing Asian Countries. Fisheries Research Journal. Elsevier. 78(2006): 130-142.

Sumaila UR and L Huang. 2012. Managing Bluefin Tuna in the Mediteranean Sea. Marine Policy. 36(2012): 502-511.

Tobin A, L Currey. C Simphe. 2013. Informing the Vulnerability of Species to Spawning Aggregation Fishing using Commercial Data Catch. Fisheries Research Journal, Elsevier. 14: 143-152.

Yonvitner, CP Lestari, A Fachrudin. 2013. Vulnerability of Purple-Spotted Bigeye, Priachanthus tayenus; Japanese Threadfin Bream, Nemipterus japonicas, Goldband Goatfish, Upeneus molucensis; Fringscale Sardinella, Sardinella fimbriata, and Indian Mackerel, Rastrellisumailager kanagurta were Captured from Sunda Strait. Jurnal Aqua Hayati (Jurnal Biosains Perairan, Perikanan dan Kelautan). 9(2): 167-176.

Wang Y, J Hu, H Pan, S Li, P Failler. 2014. An Integrated Model for Marine Fishery
Management in the Pearl River Estuary: Linking Socio-Economic Systems and Ecosystems. Marine Policy Journal, Elsevier. 64(2014): 135-147.

Wakefield CB, MJ Moran, NE Tapp, G Jackson. 2007. Catchability and Selectivity of Juvenile Snapper (Pagrus auratus, Sparidae) and Western Butterfish (Pentapodus vitta, Nemipteridae) from Prawn Trawling in a Large Marine Embayment in Western Australia. Fisheries Research Journal, Elsevier. 85(2007): 37-48.

Wiriyaphan C, H Xiao, EA Decker, J Yongsawatdigul. 2015. Chemical and Cellular Antioxidative Properties of Threadfin Bream (Nemipterus spp.) Surimi by Product Hydrolysates Fractionated by Ultrafiltration. Food Chemistry Journal, Elsevier. 167(2015): 7-15.

Walpole, RE. 1992. Pengantar statistik, edisi ke-3. Gramedia Pustaka Utama. Jakarta. 515 hal.

Yousif A. 2003. Diel Variability of Size and Catch Rate of Three fish Species and Three Penaeid Prawns in the NW Red Sea Trawl fishery. Fisheries Research Journal, Elsevier. 63(2003): 265-274.

Zeeberg JJ, A Corten, P Tjoe-Awie, J Coca, B Hamady. 2008. Climate Modulates the Effects of Sardinella aurita Fisheries Off Northwest Africa. Fisheries Research Journal, Elsevier. 89(2008): 65-75. 